\title{
An Economist's Road to Subjective Well-Being
}

\author{
Richard A. Easterlin
}

Received: 15 May 2014 / Accepted: 16 May 2014 / Published online: 28 May 2014

(C) Springer Science+Business Media Dordrecht and The International Society for Quality-of-Life Studies (ISQOLS) 2014

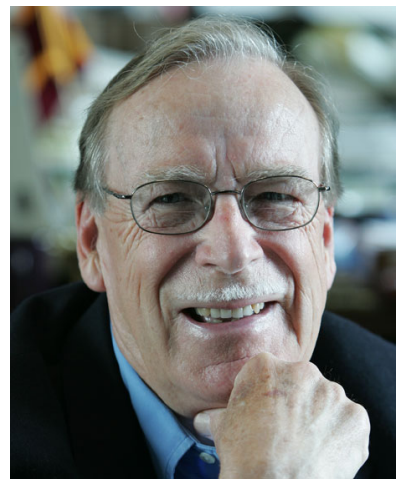

In economics, research on subjective well-being has long been stifled by a disciplinary paradigm stipulating that what people say is irrelevant to understanding their feelings or behavior. The traditional attitude of economists toward self-reports is wellcaptured by economic historian Deirdre McCloskey writing in the 1980s:

Unlike other social scientists, economists are extremely hostile toward questionnaires and other self-descriptions... One can literally get an audience of economists to laugh out loud by proposing ironically to send out a questionnaire on some disputed point. Economists... are unthinkingly committed to the notion that only the externally observable behavior of actors is admissible evidence in arguments concerning economics (McCloskey 1983, p. 514)

I was reared professionally in this belief, and was a faithful adherent for the first decade or two of my career.

R. A. Easterlin ( $\square)$

Department of Economics, University of Southern California, 3620 S. Vermont Ave. KAP 300,

Los Angeles, CA 90089, USA

e-mail: easterl@usc.edu 
My apostasy I owe to two intellectual mentors. One was Simon Kuznets, third Nobel Laureate in economics; the other, Dorothy Swaine Thomas, first woman president of the American Sociological Association. Thomas' graduate work in sociology at Columbia University had overlapped Kuznets' in economics, and both were strongly influenced there by institutional economist Wesley Clair Mitchell, one of the founding fathers of the then empirically-oriented National Bureau of Economic Research. It was my good fortune that Kuznets and Thomas were starting a collaborative research project just as I was finishing graduate school at the University of Pennsylvania, and I was invited by them to participate in the study. From Kuznets, I had learned that insight into other times and places started, not from economic theory- the accepted disciplinary approach — but from knowledge of the facts, including subjective evidence, and from studying the work of social science scholars generally, not just economists. Thomas guided me into demography, where, happily, measurement was highly regarded and self-reports conventionally accepted.

It was when I was seeking to understand the post-World War II baby boom and bust that I realized that explanations in terms of the standard economic categories of income and prices did not work, and that the role of subjective attitudes ("tastes" to economists) had to be recognized. Hence when I was a Fellow in 1970-71 at the Center for Advanced Study in the Social Sciences, the analysis of the baby boom and bust that I had developed had opened my mind to subjective testimony (cf., e.g., Easterlin 2004, chapter 11).

The Fellowship provided an opportunity for extended contact with leading scholars in sociology and psychology. When over lunch 1 day, casual mention was made of data on happiness, I saw an opportunity to test the economists' universal assumption that higher income and well-being go hand-in-hand. My own expectation by that time was of a nil relation. The actual evidence turned out to be much more intriguing - a positive point-of-time relation and nil time series association. And so was born the "Easterlin Paradox", which remains to this day alive and well, claims to the contrary notwithstanding (Easterlin 2013).

More importantly, the attitude toward subjective testimony of the discipline of economics has itself changed in the last few decades, Nowhere is this more evident than in the 2008 Stiglitz-Sen-Fitoussi Report (www.stiglitz-sen-fitoussi.fr) prepared by a 25 member Commission, including five Nobel Prize winners in economics. The Commission was established by then-French President Sarkozy to suggest better ways to measure social progress than the traditional GDP measure. Most of the Commission members had been schooled in the "behaviorist" orthodoxy of economics, as I had. Yet, writing in the first decade of this century, the Commission made a revolutionary (for economics) pronouncement:

Research has show that it is possible to collect meaningful and reliable data on subjective well-being... [T] he types of questions that have proved their value within small-scale and unofficial surveys should be included in larger-scale surveys undertaken by official statistical offices (p. 16, emphasis added).

Thirty years ago such a statement would have been economic heresy. Today, in economics it is quietly accepted, if not universally endorsed. Truly a sea change is underway in the discipline of economics. 


\section{References}

Easterlin, R. A. (2004). The reluctant economist: Perspectives on economics, economic history, and demography. New York: Cambridge University Press.

Easterlin, R. A. (2013). Happiness and economic growth: The evidence. IZA Discussion Paper 7187, forthcoming in W. Glatzer (Ed.), Global handbook of well-being and quality of life. Springer.

McCloskey, D. N. (1983). The rhetoric of economics. Journal of Economic Literature, 21(2), 481-517. 